\title{
Monitoring Scotland's transitional water fish communities under the EU Water Framework Directive
}

\author{
M. O’Reilly'1, J. Boyle, S. Nowacki, M. Elliott \& R. Foster
}

Scottish Environment Protection Agency, Angus Smith Building, 6 Parklands Avenue, Eurocentral, Holytown, North Lanarkshire ML1 4WQ

${ }^{1}$ E-mail: myles.oreilly@ sepa.org.uk

\begin{abstract}
The history of monitoring transitional water fish in Scotland is briefly outlined. The requirements of the EU Water Framework Directive are explained and how this applies to the monitoring of transitional water fish communities in Scotland is described. The development of a monitoring programme for Scotland is outlined, including sampling methods and strategies. Six transitional waters were selected as representative for Scotland covering three different types of transitional water. A multi-metric tool, the Transitional Water Fish Classification Index was used to assess the ecological status of the fish communities in these waters and the operation of the different metrics and the creation of appropriate reference conditions is explained. The assessment tool was applied to survey data from 2005 to 2018, although only the more recent data fully met the tool requirements. The species composition and abundances in the respective transitional waters were compared. The fully valid surveys were all classed as of Good or High status, indicating the fish communities in all the representative transitional waters appeared to be in good ecological health. The efficacy of the different metrics is considered and some issues with Metric 2, enumerating migratory species, are discussed at length. A new multi-metric tool, the Estuarine Multi-metric Fish Index, is briefly discussed and its introduction for the assessments in Scotland is recommended.
\end{abstract}

Supplementary Files are available at:

https://www.glasgownaturalhistory.org.uk/gn27_3/O'R eilly_etal_supplementary_files.pdf

\section{INTRODUCTION}

Transitional waters are bodies of surface water that are partly saline, such as estuaries and reduced salinity sea lochs. They are very important habitats for fish communities, including many species of commercial and conservation importance, which use them as nurseries, feeding and refuge areas, and migration routes (Elliott \& Hemingway, 2002). Estuarine fish communities may act as sentinels of ecological change and assessing their status is a key aspect of environmental monitoring (Whitfield \& Elliott, 2002). While much attention has been paid to the studies of fisheries in Scotland's fresh and marine waters, rather less effort has gone into investigations of the fish communities in transitional waters. The exception is for the estuaries of the Rivers Clyde and Forth, both of which have heavily industrialised hinterlands with consequent impacts upon their estuaries. Monitoring of the fish communities in these waters was initiated by the Clyde and Forth River Purification Boards (CRPB \& FRPB) in the late 1970s in response to water pollution concerns. Both estuaries suffered serious effects from industrial and municipal discharges, as well as impacts from diffuse pollution and land reclamation (for Clyde Estuary see Mackay et al., 1978; Hammerton, 1986, 1997; Haig, 1986; and for Forth Estuary see Elliott \& Griffiths, 1986, 1987; McLusky, 1987; Griffiths, 1987; Leatherland, 1987).

The monitoring in the Clyde and Forth Estuaries aimed to gauge the impact on the estuarine fish populations and measure recovery following implementation of the Control of Pollution Act (1974). Fish sampling was carried out quarterly, mostly using beam trawls or Agassiz trawls. In the Clyde Estuary the trawling surveys commenced in 1978 at four sites in the lower estuary, one at Pillar Bank, and three between the River Leven and Bowling (Henderson \& Hamilton, 1986). In the Forth Estuary the trawling surveys commenced in 1977 with five sites in the lower estuary (Longannet, Tancred, Bo'ness, Blackness, Port Edgar) and six sites in the upper estuary between Kincardine and Stirling (Elliott et al., 1988).

In the Clyde the work of the CRPB culminated in the return of Atlantic salmon (Salmo salar) runs in the River Clyde in 1983 after an absence of over 100 years and there is now an established fishery with annual runs of both salmon and sea trout (Salmo trutta) up into the Clyde and also now into the Kelvin (Mackay \& Doughty, 1986; Gardiner \& Armstrong, 1996; FRS, 2003). Similarly, for the FRPB the return of the smelt (or sparling: Osmerus eperlanus) to the Forth Estuary in 1989, after an absence of 25 years, was a newsworthy occurrence (Edwards, 1989). The smelt is a species of conservation interest in Scotland with populations elsewhere restricted to the Tay and the Cree estuaries. However, there is now a thriving population re-established in the Forth Estuary (Maitland \& Lyle, 1990, 1996). 
Fish sampling in these estuaries has continued for over 30 years, carried on from 1996 by the Scottish Environment Protection Agency (SEPA). The primary purpose of these surveys was to provide evidence to feed into the water quality classification schemes developed by the Association of River Inspectors for Scotland (ADRIS, 1994) for the River Purification Boards and subsequently adopted by SEPA. The ADRIS Estuary Classification Scheme included an assessment of whether the passage of migratory species was free, or partly restricted, or wholly prevented (e.g. due to dissolved oxygen deficiencies). Similarly, the resident estuarine fish fauna was assessed as to whether it was consistent with the physical and hydrographical conditions or showed a reduction in species richness and occasional or frequent restrictions in usage of the estuary due to water quality factors. The principal factor limiting migratory or resident fish was dissolved oxygen sags caused by biological oxygen demand from sewage treatment works discharges.

The fish data collected included the species present and their abundances and in most surveys the length and weight of each fish specimen was also recorded, allowing more detailed investigations of the fish population dynamics. The status of the fish community in the Clyde Estuary was described by Henderson \& Hamilton (1986). The fish data gathered from the Forth Estuary have spawned numerous publications (Poxton, 1987; Elliott et al., 1988, 1990; Elliott \& Taylor, 1989; Pomfret et al., 1991; Greenwood et al., 2002; Greenwood \& Hill, 2003). Additional studies on fish entrapped on mesh screens at the Kincardine and Longannet power stations in the Forth Estuary have also provided further information on its fish community (Greenwood, 2008a,b; Greenwood \& Maitland, 2009). The EU Water Framework Directive (2000) provided new impetus to assess the fish communities in Scotland's transitional waters and to develop new monitoring approaches which would be comparable throughout the U.K. and Europe.

\section{THE EU WATER FRAMEWORK DIRECTIVE (WFD)}

The EU Water Framework Directive (European Union, 2000) involves an integrated approach to assessing ecological quality in fresh waters, transitional waters, and coastal waters. Guidance on implementing WFD in these waters is provided via common implementation strategy documents (WFD-CIS, 2003a,b). The ecological communities assessed for transitional and coastal waters include benthic invertebrates, macroalgae/seagrasses, and phytoplankton; under WFD the fish communities are assessed in fresh waters and transitional waters but not in coastal waters where fisheries are regulated under the Marine Strategy Framework Directive and the EU Common Fisheries Policy (Greenstreet et al., 2012).

The different ecological communities (called Biological Quality Elements under WFD) are assessed using different analytical tools to produce an ecological status or WFD class. There are five classes (High, Good,
Moderate, Poor and Bad) which reflect an increasing gradient of environmental pressure and exhibit increasing deviation from completely natural reference conditions.

The assessment tools must each produce a score, called an Ecological Quality Ratio (EQR), which ranges between 0 and 1 and this range is divided into the five quality classes with 0 being at the lower end of Bad and 1 at the upper end of High. Moreover, a Good status in one country, for any biological quality element, must mean the same as in any other country. This is checked by a formal intercalibration process where countries compare results from different assessment tools for the same biological quality element using a common dataset for that element. Where results differ the class boundaries of specific assessment tools are adjusted so that the tools will provide similar classifications for relevant ecological data (Lepage et al., 2013, 2016).

\section{IMPLEMENTING THE DIRECTIVE}

To implement WFD in the U.K. a Technical Advisory Group (UKTAG) was established and a task team formed for each biological quality element. The UKTAG Transitional Water Fish Task Team developed and tested assessment tools and provided guidance on monitoring strategies and sampling methods in readiness for commencing WFD monitoring in 2007 (Coates et al., 2004, 2007). The recommended monitoring strategy involved annual sampling in representative transitional waters of different ecotypes. A multi-method sampling approach was proposed using a range of different fishing gear. The sampling programmes aimed to sample throughout the transitional water, in shallow and deep water, in inner and out parts of the water body, to gauge all components of the fish community. Depending on the size of the water body between 30 and 50 samples were deemed appropriate to characterise the fish community. Fish sampling was targeted in spring and autumn or, failing that, a more intense autumn sampling should suffice. The Transitional Fish Classification Index (TFCI) developed by Coates et al. (2007) was adopted as the assessment tool for fish communities in the U.K. (and Ireland). The application of this tool in the U.K. has been described in some detail in a UKTAG method statement and practitioner's guide (WFD-UKTAG, 2012, 2014a).

Although Scotland has over 500 marine water bodies designated under WFD, only 49 of these are categorised as transitional waters. Six different types of transitional waters are recognised within the UK (WFD-UKTAG, 2003) but only four of these types are found in Scotland. Of Scotland's estuaries, 27 are partly mixed/stratified, meso-/polyhaline, and mesotidal (Type TW2), and ten, situated in the Solway region, are mixed/stratified, meso-/polyhaline, and macrotidal (Type TW3). Scotland has 110 sea lochs (Edwards \& Sharples, 1986) but only four of these have sufficient freshwater input to categorise them as Transitional Sea Lochs (Type TW5). Scotland has 103 saline lagoons (Angus, 2016) but only those 8 lagoons that are actually connected to an 
adjacent transitional water are categorised as Transitional Lagoons (Type TW6).

While member states are required to provide classifications for all water bodies, they do not need to monitor all of them. Surveillance monitoring of a selection of water bodies that are representative of the different types is sufficient, along with monitoring of any other water bodies under significant anthropogenic pressure and at risk of being at less than Good ecological status. Results of the surveillance monitoring of one water body can be attributed, as proxies, to a group of similar water bodies with similar pressures. SEPA had previously monitored fish populations in the Clyde and Forth Estuaries, and had also conducted a little sampling in the Tay Estuary. In preparation for WFD monitoring, some additional fish surveys were undertaken in the Dornoch, Cromarty, and Beauly/Moray Firths (SEPA, 2005) as well as in Loch Eil, Gare Loch, and the Garnock Estuary. From all of these, six transitional waters were eventually selected as representative for Scotland's Transitional Water Fish assessments, with two from the east coast (North Sea Ecoregion) and four from the west coast (Atlantic Ecoregion) (Fig. 1). These six selected transitional waters actually comprise ten water bodies and have 13 associated water bodies which receive grouped classification from their parent water body (Table 1). For the other 26 transitional water bodies, remote from anthropogenic pressures and not included within any groups, the classification defaults to High for TW fish.

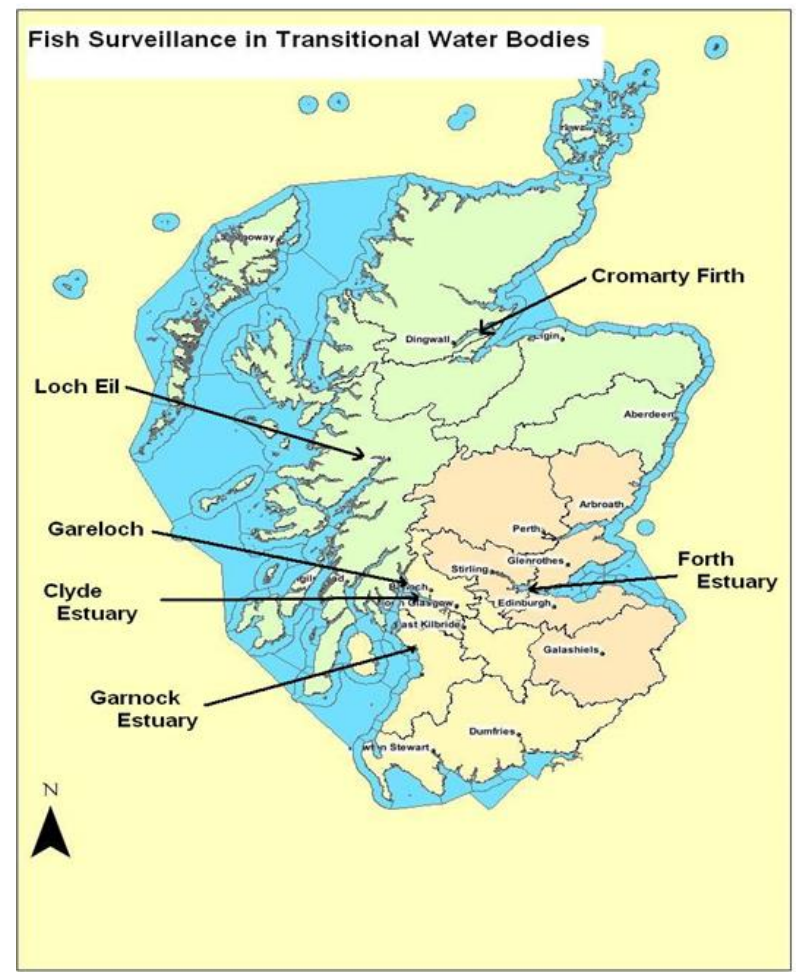

Fig. 1. Location of representative transitional waters for assessing transitional water fish communities. Marine water bodies shown in blue.

It should be noted that some of the transitional waters actually comprise more than one defined water body for
WFD assessments (e.g. the Forth Estuary is composed of three water bodies - Upper, Middle, and Lower Forth Estuary) but, in contrast to other biological quality elements, the relatively mobile fish community is always monitored, assessed, and classified as a single entity across the whole estuary.

The Clyde and Forth are large estuaries with significant anthropogenic pressures. The Cromarty Firth and Garnock/Irvine are smaller estuaries with fewer pressures. Loch Eil and Gare Loch are transitional sea lochs with differing pressures. Although there are several macrotidal (TW3) water bodies along the Dumfries and Galloway coast, the fish communities here have not been assessed by SEPA, as the macrotidal régime makes field sampling very difficult and potentially dangerous. However, the Solway Estuary water body itself (which is a cross-border water body) is surveyed for fish on the English side and a classification for its transitional water fish is provided by the Environment Agency. The WFD UKTAG Transitional Waters Fish Task Team has taken the view that transitional water lagoons (TW6) are not appropriate for fish assessment as these water bodies are typically isolated from the sea, and their utilisation by marine fish species is probably very limited.

\section{The Scottish TW Fish Monitoring Programme}

Although some preliminary WFD surveys began in 2005, the monitoring programme for TW fish did not start properly until 2007 with the gradual introduction of the multi-method sampling approach in the representative transitional waters (Table 2). The methods utilised large and small beam trawls, pelagic trawls, beach seines, and fyke nets.

The large beam trawls were towed in deeper water along pre-set routes, usually between 0.6 and $1 \mathrm{~km}$ in length, using the SEPA survey vessel, Sir John Murray, or occasionally on the east coast, the Alba na Mara survey vessel from Marine Scotland. The SEPA beam trawl has a $2 \mathrm{~m}$ width metal frame with shoes on the lower side with $70 \mathrm{~mm}$ main mesh net and $40 \mathrm{~mm}$ cod-end mesh. The Marine Scotland beam trawl has a similar $2.7 \mathrm{~m}$ frame with $90 \mathrm{~mm}$ main mesh net and $50 \mathrm{~mm}$ cod-end mesh. The beam trawl catches were landed on deck and all the contained fish transferred to tubs for processing (Fig. 2A). In the Forth and Tay estuaries an Agassiz type beam trawl was used at deeper sites up until 2008 but replaced thereafter with a standard $2 \mathrm{~m}$ metal beam trawl. Pelagic mid-water trawls were trialled in the outer reaches of the Forth and Tay estuaries, and the Cromarty Firth, up until 2009, and also in the Clyde in 2010. However, the UKTAG Team then recommended against using pelagic trawls as they could be operated in only very limited areas, and potential catches of large shoals of pelagic fish, such as sprats (Sprattus sprattus), may skew the overall abundance data for the estuary. Hence, this sampling method was not used after 2010.

In shallower waters, a lighter $2 \mathrm{~m}$ width wooden beam (with metal shoes) was used or a shoeless mini-beam trawl, $1.5 \mathrm{~m}$ metal bar width and $10 \mathrm{~mm}$ mesh. The beam 


\begin{tabular}{|c|c|c|c|}
\hline Type & Location & Surface Area $\left(\mathrm{Km}^{2}\right)$ & Grouped water bodies. \\
\hline TW2 & Cromarty Firth & 90.9 & $\begin{array}{l}\text { Dornoch Firth, Moray Firth, Beauly Firth, Lossie Estuary, Eden Estuary, } \\
\text { Montrose Basin }\end{array}$ \\
\hline TW2 & Forth Estuary & 86.5 & Tay Estuary \\
\hline TW5 & Loch Eil & 11.2 & Loch Linnhe (North), Loch Etive. \\
\hline TW5 & Gare Loch & 12.8 & None \\
\hline TW2 & Clyde Estuary & 75.2 & None \\
\hline TW2 & Garnock/Irvine Estuary & 1.6 & Ayr Estuary, Girvan Estuary, Stinchar Estuary \\
\hline
\end{tabular}

Table 1. Representative transitional waters for fish assessment in Scotland.

\begin{tabular}{|c|c|c|c|c|c|c|c|c|c|}
\hline Year & $\begin{array}{l}\text { Beauly / } \\
\text { Moray }\end{array}$ & $\begin{array}{l}\text { Dornoch } \\
\text { Firth }\end{array}$ & Cromarty Firth & Tay Estuary & Forth Estuary & Clyde Estuary & $\begin{array}{l}\text { Garnock } \\
\text { Estuary }\end{array}$ & Loch Eil & Gare Loch \\
\hline 2005 & $9 \mathrm{~B}, 2 \mathrm{~F}, 3 \mathrm{~S}$ & $4 \mathrm{~B}, 1 \mathrm{~F}, 1 \mathrm{~S}$ & $14 \mathrm{~B}, 2 \mathrm{~F}, 3 \mathrm{~S}$ & $12 \mathrm{~B}, 1 \mathrm{~F}, 1 \mathrm{~S}, 4 \mathrm{P}$ & 42B & 12B & - & $4 \mathrm{~B}$ & - \\
\hline 2006 & - & - & - & - & $28 \mathrm{~B}, 4 \mathrm{P}$ & $8 \mathrm{~B}$ & - & - & - \\
\hline 2007 & - & - & $13 \mathrm{~B}, 4 \mathrm{~F}, 5 \mathrm{~S}, 2 \mathrm{P}$ & $2 \mathrm{~B}, 1 \mathrm{P}$ & $24 \mathrm{~B}, 6 \mathrm{P}$ & 14B & $2 \mathrm{~F}$ & $4 \mathrm{~B}$ & $10 \mathrm{~B}$ \\
\hline 2008 & - & - & $10 \mathrm{~B}, 4 \mathrm{~F}, 4 \mathrm{~S}, 1 \mathrm{P}$ & $8 \mathrm{~B}, 2 \mathrm{~F}, 1 \mathrm{~S}, 1 \mathrm{P}$ & $26 \mathrm{~B}, 1 \mathrm{~F}, 1 \mathrm{~S}, 3 \mathrm{P}$ & $9 \mathrm{~B}$ & $2 \mathrm{~F}$ & $6 \mathrm{~B}$ & $9 \mathrm{~B}$ \\
\hline 2009 & - & - & $2 \mathrm{~F}, 1 \mathrm{~S}, 2 \mathrm{P}$ & $2 \mathrm{~B}, 2 \mathrm{~F}, 2 \mathrm{~S}, 1 \mathrm{P}$ & $36 \mathrm{~B}, 2 \mathrm{P}$ & $11 \mathrm{~B}$ & $2 \mathrm{~F}$ & $6 \mathrm{~B}$ & $7 \mathrm{~B}$ \\
\hline 2010 & - & - & - & - & - & $12 \mathrm{~B}, 4 \mathrm{~F}, 4 \mathrm{~S}, 8 \mathrm{P}$ & $4 \mathrm{~F}, 6 \mathrm{~S}$ & - & $8 \mathrm{~B}, 3 \mathrm{~F}, 5 \mathrm{~S}$ \\
\hline 2011 & - & - & - & - & $15 \mathrm{~B}, 4 \mathrm{~F}, 10 \mathrm{~S}$ & $8 \mathrm{~F}, 12 \mathrm{~S}$ & - & - & - \\
\hline 2012 & - & - & $24 \mathrm{mB}, 8 \mathrm{~F}, 16 \mathrm{~S}$ & - & - & $8 \mathrm{~F}, 8 \mathrm{~S}$ & - & $10 \mathrm{~B}, 8 \mathrm{~F}, 19 \mathrm{~S}$ & - \\
\hline 2013 & - & - & - & - & - & $10 \mathrm{~B}, 8 \mathrm{~F}, 18 \mathrm{~S}$ & $7 \mathrm{mB}, 10 \mathrm{~F}, 16 \mathrm{~S}$ & - & $10 \mathrm{~B}, 8 \mathrm{~F}, 16 \mathrm{~S}$ \\
\hline 2014 & - & - & - & - & $9 \mathrm{~B}, 14 \mathrm{mB}, 8 \mathrm{~F}, 16 \mathrm{~S}$ & - & - & - & - \\
\hline 2015 & - & - & $21 \mathrm{mB}, 9 \mathrm{~F}, 12 \mathrm{~S}$ & - & - & - & - & $6 \mathrm{~B}, 4 \mathrm{mB}, 10 \mathrm{~F}, 18 \mathrm{~S}$ & - \\
\hline 2016 & - & - & - & - & - & $10 \mathrm{~B}, 15 \mathrm{~F}, 20 \mathrm{~S}$ & - & - & - \\
\hline 2017 & - & - & - & - & $12 \mathrm{mB}, 3 \mathrm{~F}, 8 \mathrm{~S}$ & - & - & - & - \\
\hline 2018 & - & - & - & - & $4 \mathrm{~B}$ & - & - & - & - \\
\hline
\end{tabular}

Table 2. Sampling programme and methods for transitional water fish, 2005-2018. B = beam trawl; $F=$ fyke net; $\mathrm{S}=$ seine net; $\mathrm{P}=$ pelagic trawl; $\mathrm{mB}=$ mini-beam trawl. 
trawls in shallower water were towed, for five or ten minutes, from various smaller craft, including RIBs (Fig. 2B). On shallow shelving shores beach seine nets were used with a two or three metre curtain wall and about $30 \mathrm{~m}$ long, with $6.5 / 14 \mathrm{~mm}$ mesh. The beach seines were dragged out in a large loop by wading out chest deep, or pulled out by a small rigid inflatable boat (RIB), and then hauled shoreward to encircle whatever fish were in the vicinity (Fig. 2C). In addition, doubleended fyke nets were deployed in shallow waters. These nets were 7-hoop large Double Dee, $1 \mathrm{~m}$ height, $10 / 14 \mathrm{~mm}$ mesh, with $10.6 \mathrm{~m}$ leader (no wings) or 5-Hoop Double-O, 10/14/17 mm mesh with 5.5 m leader and side wings, and all fitted with otter-guards. The fyke nets were staked in place with metal road pins at low water with just enough water to cover the trap ends and left for 12 hours to trap fish over one tidal cycle (Fig. 2D). Alternatively, the fyke nets could be lowered into shallow water from a RIB, with a small marker buoy and anchors/chains at either end to keep them in place for the duration of one or two tidal cycles. For all samplings all captured fish were transferred to holding tubs and then identified and measured and returned alive to the water. The topography and bathymetry of the transitional water dictated what type of fishing gear was appropriate and where it could be used, with the underlying aim of sampling all components of the fish
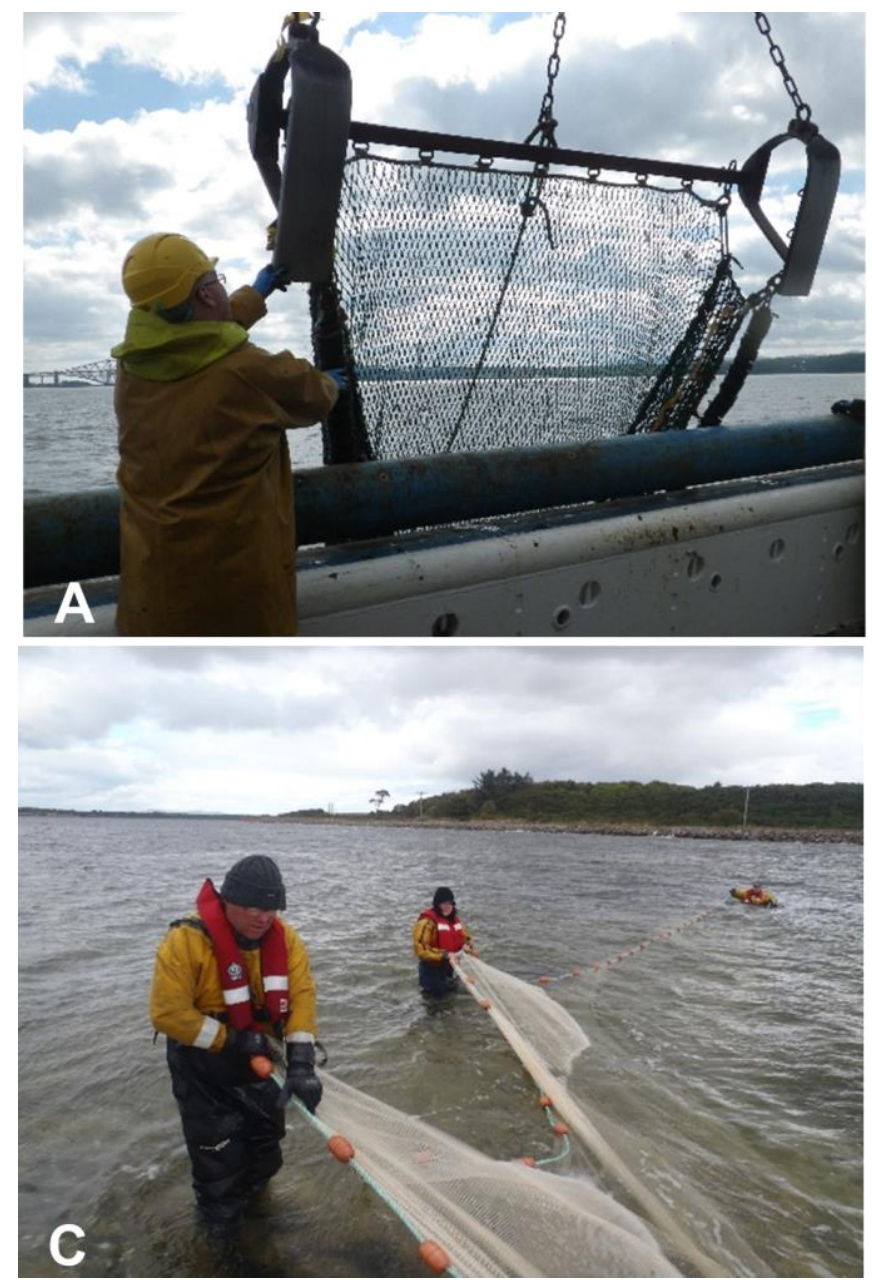

community throughout the transitional water. As there were slight variations in gear, mesh sizes, trawl lengths or times, then the methods are not fully standardised and the resultant data are only semi-quantitative. Nevertheless these data are fit for the purposes of WFD qualitative assessments. The array of sampling sites and methods for the different transitional waters are shown in Fig. 3. Fish identification followed the standard guide for British and Irish waters (Maitland \& Herdson, 2009).

The recommended sampling windows were spring (May/June) or autumn (September/October). It quickly became apparent that sampling of all six transitional waters every year was logistically unrealistic and SEPA adopted a programme of sampling each transitional water every third year. This would allow two classifications to be undertaken within each six-year WFD reporting cycle. In the first few years both spring and autumn sampling was carried out, but in later years it proved more efficient to focus all the sampling in autumn. Even then logistical issues arose and some transitional waters, such as the Clyde Estuary, were surveyed over two years, with the inner estuary one year and the outer estuary the following year. In such cases the data were amalgamated as if they came from a single year.
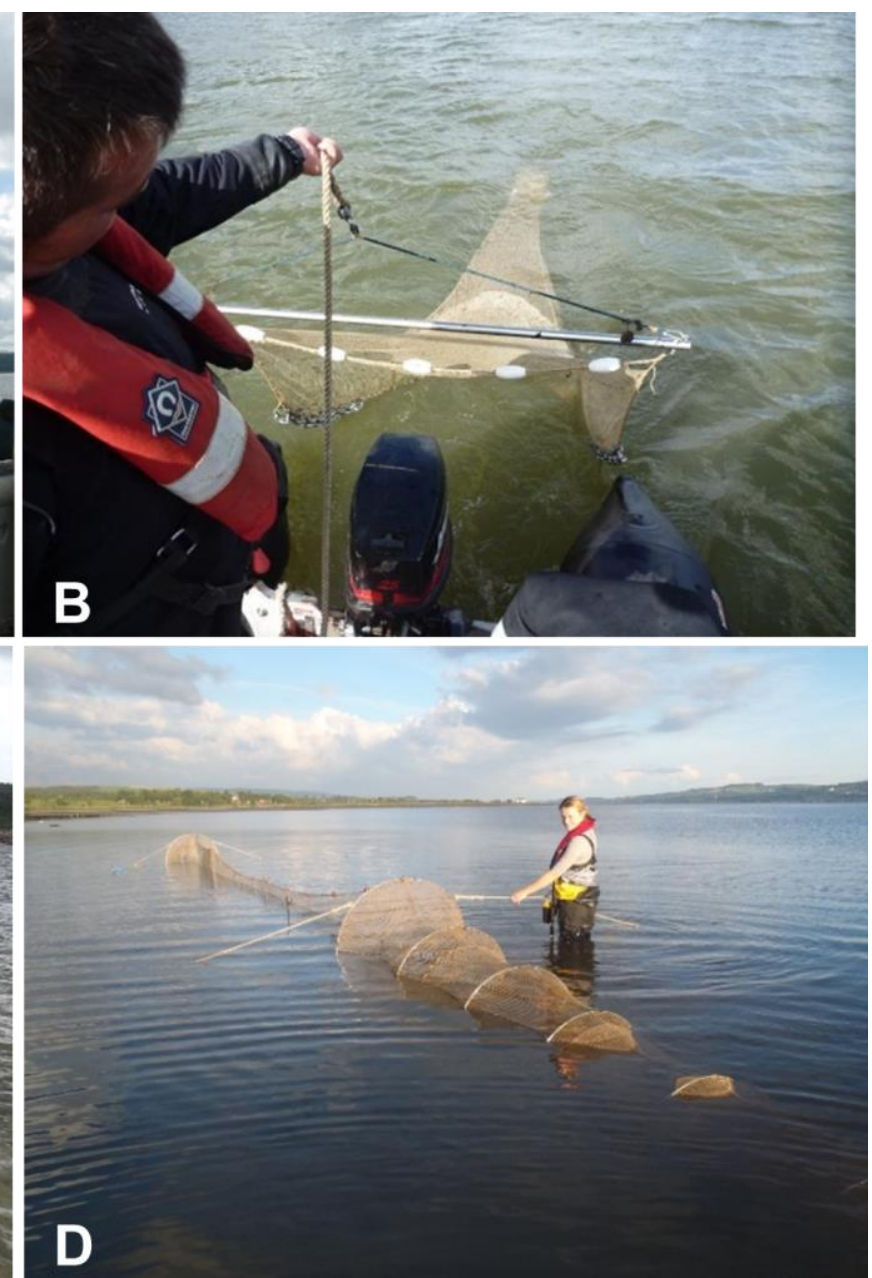

Fig. 2. Sampling gear. (A) Beam trawl. (B) Mini-beam trawl. (C) Beach seine. (D) Fyke net. (Photos: SEPA (A,C,D); DAERA NI (B)) 


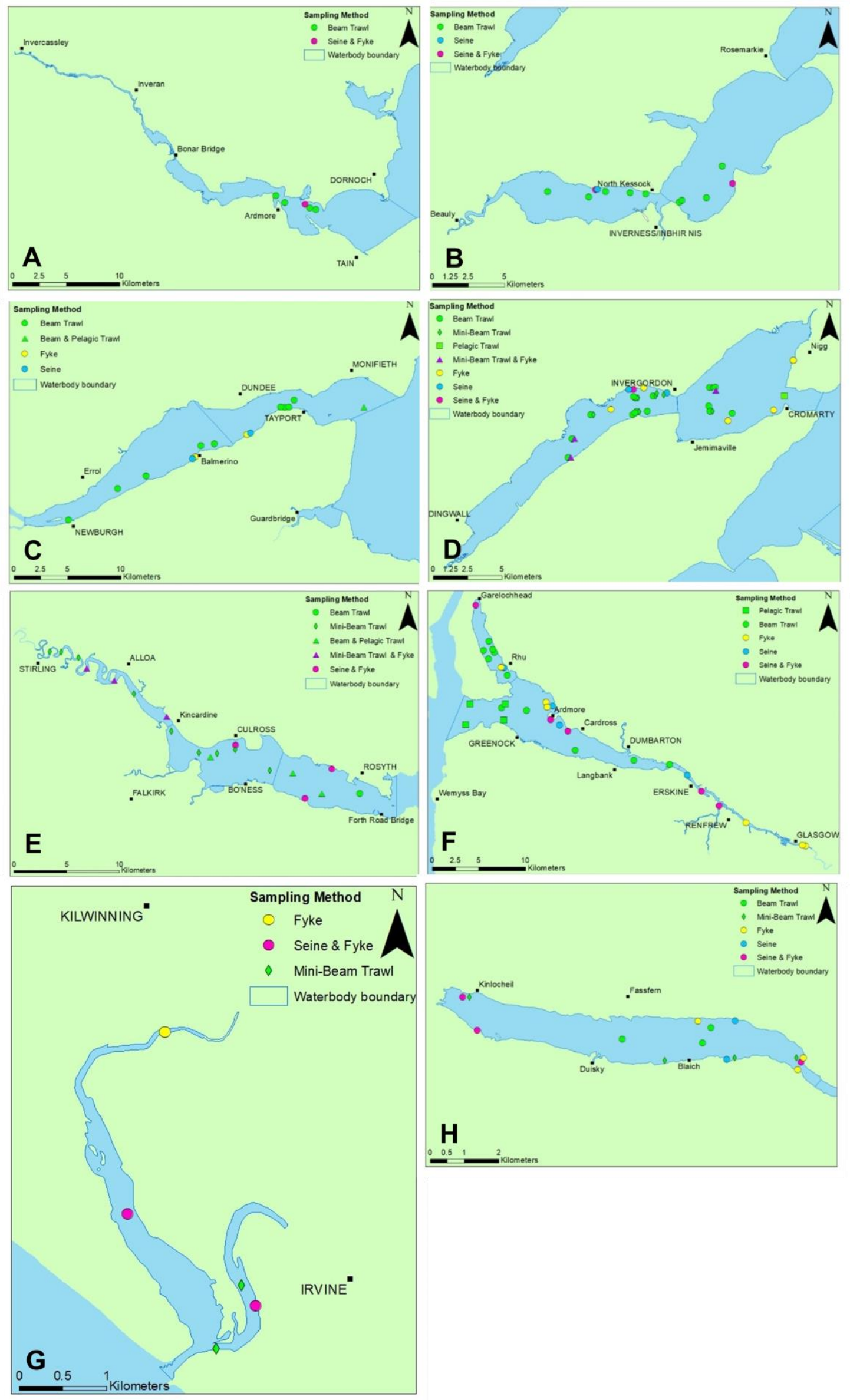

Fig. 3. Sampling sites and methods. (A) Dornoch Firth, 2005. (B) Beauly/Moray Firth, 2005. (C) Tay Estuary, 2005-09. (D) Cromarty Firth, 2005-15. (E) Forth Estuary, 2005-18. (F) Clyde Estuary and Gare Loch, 2005-16. (G) Garnock/Irvine Estuary, 2007-13. (H) Loch Eil, 2005-15. 


\section{The Transitional Water Fish Classification Index (TFCI)}

The directive requires member states to examine the composition and abundance of the ecological communities and any sensitive species therein and gauge how far these have deviated from natural reference conditions. The TFCI assessment tool developed by the UKTAG Transitional Water Fish Task Team comprises ten community metrics of ecological relevance which evaluate the species diversity or composition, the species abundance, the nursery function and also the trophic integrity (WFD-UKTAG, 2014a).

The assessment tool requires that each fish species is categorised into specific ecological guilds following the approach developed by Elliott \& Dewailly (1995), Elliott \& Hemingway (2002), Elliott et al. (2007), and Franco et al. (2008). The TFCI tool utilises functional guilds and feeding guilds (WFD-UKTAG, 2012, 2014a). Functional guilds describe the lifestyle of a fish species - how it uses the estuary or transitional water. Estuarine Residents (ER) live their full lives in the estuary, and include species such as flounder (Platichthys flesus), eelpout (Zoarces viviparus), pogge (Agonus cataphractus), and sand goby (Pomatoschistus minutus). Marine Seasonals (MS) are marine fish which enter estuarine waters on a seasonal basis only and include species such as sprat, thicklip grey mullet (Chelon labrosus), grey gurnard (Eutrigla gurnardus), and five-bearded rockling (Ciliata mustela). Marine Juveniles (MJ) only spend the younger stages of their lives in estuaries, using the estuary as a nursery, and move back into fully marine waters as they mature. These include many important commercial fish species such as common dab (Limanda limanda), plaice (Pleuronectes platessa), common sole (Solea solea), herring (Clupea harengus), cod (Gadus morhua), whiting (Merlangius merlangus), and pollack (Pollachius pollachius), as well as smaller species such as sand smelt (Atherina presbyter). Catadromous and anadromous (CA) fish migrate from marine waters to freshwater to breed such as salmon, sea trout, smelt, river and sea lampreys (Lampetra fluviatilis and Petromyzon marinus), or vice versa for the European eel (Anguilla anguilla). They all pass through estuarine waters, where they may spend some time, and many of these species are particularly sensitive to reduced water quality or physical barriers and for this reason are regarded as indicator species. Some indicator species, such as the allis shad (Alosa alosa) and twaite shad (A. fallax) are now very scarce in Scottish waters, and others such as the sturgeon (Acipenser sturio) have long been extinct, apart from an occasional vagrant from elsewhere in Europe. Marine Adventitious (MA) species are marine species that are occasional visitors and wander into the estuary by accident. They include a wide variety of marine species and sometimes very unusual vagrants may turn up, such as a swordfish (Xiphias gladius) observed in the Forth Estuary in 2009 (BBC, 2009) and more recently in the Firth of Forth (McInerny \& Hoey, 2021). Freshwater fish (FW) also form a functional guild that occasionally appears in the upper parts of estuaries, especially during high river flows.

The feeding guilds describe the predominant feeding mode or diet of a species. Most demersal fish are benthic invertivores (BI) - feeding on invertebrates on the seabed. These include flatfish (Pleuronectiformes), gurnards (Triglidae), gobies (Gobiiformes), and sea scorpions (Cottidae). Zooplanktivores (Z) pluck their prey from the water column and include herring, sprat, sandeels (Ammodytes spp.), smelt, sand smelt, as well as pipefish (Syngnathidae), and sticklebacks (Gasterosteidae). Piscivores (P) prey on other fish species and include salmon, cod, whiting, saithe (Pollachius virens), bullrout (Myoxocephalus scorpius), European eel, seabass (Dicentrarchus labrax), and also the parasitic sea and river lampreys. Finally, the grey mullets are categorised as detritivores (D) feeding on various types of organic detritus. It should be noted the feeding guilds allocated refer to the dominant feeding modes of adults. Salmon may be invertivores for parts of their life cycle and larval lampreys are filter-feeding detritivores.

\section{Reference conditions and metric calculations}

Once all the fish species and abundance data have been collected and the species allocated to their respective functional and feeding guilds, the ten metrics can then be calculated. However, the directive requires assessments of each biological quality element with respect to natural reference conditions for that ecological community. This means that a reference condition value for each metric in the TFCI is needed. Moreover, a separate set of reference conditions is required for each transitional water type and/or ecoregion. Hence, for Scottish waters these baseline reference conditions needed to be created by SEPA for North Sea TW2, Atlantic TW2, and Atlantic TW5 transitional waters.

Constructing reference conditions for all the metrics used an amalgamation of historical species richness records and more recent survey data on species occurrences and abundances. Such reference conditions based on scant historical records and limited datasets are far from ideal but do at least provide a standardised baseline using the best information available. The finalised Reference Condition spreadsheets are held by SEPA and copies are used as workbook templates for carrying out subsequent classifications. The Scottish reference condition values for transitional waters fish are presented in the TFCI Method and the Practitioner's Guide (WFD-UKTAG, 2012, 2014a) along with notes on calculating the metrics and carrying out an assessment and classification.

The approach to developing Scottish reference conditions is described here for the first time and involved some hindcasting by looking at historical records of fish in Scottish transitional waters and also looking at more recent fish datasets to determine the most suitable data which can be used to set a boundary for reference conditions. As the Scottish survey data are 
limited to only a few transitional waters they were augmented with transitional water fish data from nearby regions with similar water body types. For TW2 (North Sea), SEPA survey data from the Cromarty, Forth, and Tay from 2005-12 was used with additional data provided from the Environment Agency surveys in north-east England from the Coquet, Esk, Tees, Tweed, Tyne and Wear Estuaries over 2010-12. For TW2 (Atlantic), SEPA data from the Clyde and Garnock from 2005-11 was used with additional data provided from Northern Ireland Environment Agency surveys in the Bann, Connswater, Foy and Fau, Laggan, Newry, and Roe Estuaries over the period 2010-11. For TW5 (Atlantic) SEPA data from Gare Loch and Loch Eil from 2005-12 was used with additional survey data provided from the Scottish Marine Biological Association (SMBA) surveys in Loch Eil and Loch Etive over the period 1968-76.

For species richness, the historical records for a transitional water are treated as if they were a single annual survey and ranked with the recent annual survey data from relevant surveys. The upper five ranked surveys with the highest species richness were taken as a quintile cut-off for the reference condition value range. The historical literature consulted to help construct reference conditions is shown in Supplementary File 1. For estimating historical species richness for the North Sea TW2 all historical species records from the Cromarty Firth and the Tay and Forth Estuaries were collated. Added to these were any fish species records of the ER, MJ, MS, CA, and FW functional guilds recorded from adjacent coastal waters bodies or upstream riverine water bodies. However, the availability of historical data was skewed towards the Forth such that it had 67 species, with only 20 species from the Cromarty and eight from the Tay. The historical species richness records form the Cromarty Firth and Forth and Tay Estuaries were ranked against more recent data from 2005-12, and data from the NE England estuaries from 2010-12. Similarly for the Atlantic TW2, any historical records from the Clyde Estuary were collated and added to these were any fish species of the ER, MJ, MS, CA, and FW functional guilds recorded from the adjacent Clyde Sea Area coastal waters bodies or upstream riverine water bodies. The historical species richness for the Clyde Estuary and adjacent Clyde Sea Area was 58 species which was ranked against the recent datasets from the Clyde, the Garnock and Northern Ireland, with the upper quintile cut-off used as before to define the reference value range. However, for Atlantic TW5 no appropriate historical data was available, so just the SEPA 2005-12 and SMBA 1968-76 survey data from Gare Loch, Loch Eil, and Loch Etive were used for ranking without adding any records from adjacent coastal waters, and the upper quintile cut-off used as before to define the reference conditions range.

For the metrics in the TFCI tool the uppermost reference value is either the maximum value found using the reference survey data or, for Metric 2, Metric 7, and Metric10, the maximum possible value. This maximum value is divided into five equal bands with the upper band being the reference condition value range. Each of the five bands of metric values is assigned an individual metric score which can only be a whole number between 1 and 5, with the lower band scoring 1 and the upper band, the reference condition range, being score 5 . It is the metric scores (not the metric values) that are added to produce the final Ecological Quality Ratio (EQR).

For Metric 1 (species composition) reference value the species from all the surveys are ranked according to their frequency of occurrence over the survey/sampling years, with most frequent ranked first, and the species richness value cut-off number (as derived above) now used to determine the number of upper ranked species that appear as the Metric 1 reference list species. Metric 1 calculation involves a Bray-Curtis similarity analysis between the species captured and the reference list species. The Bray-Curtis percentage similarity is divided into five equal bands of $20 \%$ to give five possible metric scores. For TW2 (North Sea), TW2 (Atlantic), and TW5 the number of reference species is 22, 26, and 29 respectively (WFD-UKTAG, 2012, 2014a) with the relevant reference species highlighted in bold in the Supplementary Files.

For Metric 2 (number of indicator species) the reference value is where all nine indicator species (see above under CA guild) are present and for Metric 2 calculation the number of indicator species captured is compared with this. The reference value of 9 is divided into five equal bands to give five possible metric scores.

For Metric 3 (species relative abundance) reference value, the percentage proportionate abundance of each species per sampling year is calculated, and then the average relative abundance over the survey/sampling years is ranked, with highest relative abundance ranked first. Again, the upper quintile value for species richness (as described above) is used to determine the number of top-ranked species that appear as the Metric 3 reference species. The actual reference species selected is likely to differ (albeit slightly) from those in Metric 1. Metric 3 calculation involves a Bray-Curtis similarity analysis between the relative abundances of the species captured and the relative abundances of the reference list species as shown for each type in the Practitioner's Guide (WFD-UKTAG, 2012, 2014a) and also shown in the Supplementary Files. The Bray-Curtis percentage similarity is divided into five equal bands of $20 \%$ to give five possible metric scores.

For Metric 4 (number of species within $90 \%$ abundance) reference value, the percentage proportionate abundances of each species per survey/sampling year is used to determine the number of species comprising $90 \%$ abundance by selecting the most abundant species first. The number of species per sampling year is then ranked (with highest number of species ranked first) and the average of the upper quintile of the ranking used as the reference value. For Metric 4 the reference value is divided into five equal bands to give five possible metric scores. 
Metrics 5 to 10 simply involve counting the number of species present within a specific functional or feeding guild (i.e. number of species in ER, MS/MJ, BI, and P for Metrics 5, 6, 8 and 9), or the number of functional or feeding guilds present for Metric 7 and Metric 10. Reference values for metrics 5, 6, 8 and 9, involve counting the no. of species in the respective guild per survey/sampling year and ranking these, with highest first, and taking the average of the top quintile as the reference value. Metric 6 (Estuary Dependent Species) is a simple combination of the number of Marine Seasonal (MS) and Marine Juvenile (MJ) species. For Metric 7 and Metric 10 the reference value is the presence of all six functional guilds or all four feeding guilds. For Metrics 5 to 10 the reference value is divided into five equal bands to give five possible metric scores. The reference condition range of values (i.e. the upper fifth band) for Metrics 1 to 10 for TW2 (North Sea), TW2 (Atlantic), and TW5 are shown in Tables 3 - 5.

The TFCI is the sum of all ten metric scores. As these scores are whole numbers between 1 and 5 then the TFCI range has a minimum value of 10 and maximum of 50. To convert this range to an Ecological Quality Ratio (EQR), simply take the (score sum - 10) and divide by 40 which produces an EQR range between 0 and 1 , as required by the directive. The class boundaries for the EQR are initially set by dividing the EQR into five equal class bands (i.e. $0-<0.2,0.2-<$ $0.4,0.4-<0.6,0.6-1.0)$ but these are then adjusted following intercalibration with other EU member states where a common data set for each particular biological quality element was analysed by the different tools used in each member state (European Commission, 2013; Lepage et al., 2013, 2016). Only the boundaries between High/Good and Good/Moderate were reset during intercalibration (High is $0.81-1.0$, Good is $0.58-<$ 0.81 ) as these are the most crucial boundaries with respect to a member state having, or not having, to introduce improvement measures.

\section{RESULTS}

\section{Survey findings}

Between 2005 and 2018, SEPA carried out 44 assessments of fish communities in nine different transitional waters. A total of 912 samples were collected, using five different sampling methods, which captured 39,563 fish of 67 different species. The species captured and the abundances per sampling year are shown in Supplementary Files 2-4.

Preliminary surveys in the Dornoch Firth (Fig. 3A), the Beauly/Moray Firths (Fig. 3B), and the Tay Estuary (Fig. 3C) are included here, although none of these was adopted as representative transitional waters. It should be noted that the initial surveys in selected transitional waters have not always employed a multi-method sampling approach nor has the sampling effort been spread across the transitional water or attained the 30 samples deemed sufficient for confident WFD assessment. Hence, only a limited number of later surveys are fully valid for undertaking WFD assessments. No fish surveys have been undertaken since 2018 .

For TW2 estuaries on the east coast (North Sea Ecoregion) the surveys, with 488 samples, have landed 14,906 fish with 45 species recorded (Supplementary File 2). The most abundant fish were sprat $(5,693)$, flounder $(2,567)$, plaice $(1,495)$, cod $(1,403)$, whiting (622), smelt (542), and herring (518), with smaller numbers of sand goby (493), pogge (317), bullrout (261), and common goby (Pomatoschistus microps) (164). Some species such as haddock (Melanogrammus aeglefinus), ling (Molva molva), lesser sand-eel (Ammodytes marinus), two-spotted goby (Gobiusculus flavescens) and mackerel (Scomber scombrus) are represented by single specimens only. The sampling effort in the Dornoch Firth, Beauly/Moray Firths, and the Tay Estuary is insufficient to characterise the fish communities in these water bodies, though it is noteworthy that the Tay Estuary sampling does highlight the presence of smelt, as well as a few sea trout, salmon, and river lampreys.

The Cromarty Firth (Fig. 3D) harboured 35 species with a total catch of 3,126 fish for 167 samples. This was dominated by sprat, representing $60 \%$ of the total Cromarty catch, but these mostly derive from 1,851 fish captured in shoals in 2009 and 2012. Other common Cromarty fish included bullrout (108), cod (79), pogge (63), saithe (56), flounder (53), three-spined stickleback (Gasterosteus aculeatus) (52) and whiting (50). There were only a few migratory fish captured; sea trout (19), salmon (7), and European eel (2).

The Forth Estuary (Fig. 3E) harboured 35 species with a total catch of 10,478 fish for 274 samples. The Forth Estuary is similar in size to the Cromarty Firth and the same number of species was recorded. However, the overall sampling effort is much greater in the Forth which explains the higher total fish catch. Again, the catch is dominated by sprat $(3,734)$, which account for $36 \%$ of the total abundance, but $71 \%$ of the sprat derive from shoals captured by beach seining at Limekilns in 2011. The next most dominant fish was flounder $(2,391)$, which represents $23 \%$ of the total Forth catch. Other common Forth fish include plaice (937), cod (778), whiting (531), smelt (481), herring (465), sand goby (445), and pogge (228). It is evident that the Forth Estuary still functions as an important nursery area for commercial fish species as described by Elliott et al. (1990). In addition to the smelt, other migratory species occurred in small numbers: European eel (20), sea trout (13), river lamprey (7), and salmon (2).

For TW2 estuaries on the west coast (Atlantic Ecoregion) the surveys, with 240 samples, have landed 18,687 fish with 42 species (Supplementary File 3). The Clyde Estuary is nearly fifty times larger than the Garnock Estuary and has had nearly four times the sampling effort, so unsurprisingly $92 \%$ of the total catch was recovered from the Clyde. 


\begin{tabular}{|c|c|c|c|c|c|c|c|c|c|}
\hline Metric & $\begin{array}{l}\text { Ref. } \\
\text { Values } \\
\text { Range }\end{array}$ & $\begin{array}{l}\text { Cromarty } \\
2012 \\
\text { Values }\end{array}$ & $\begin{array}{l}\text { Cromarty } \\
2015 \\
\text { Values }\end{array}$ & $\begin{array}{l}\text { Forth } \\
2014 \\
\text { Values }\end{array}$ & $\begin{array}{l}\text { Forth } \\
2017 / 18 \\
\text { Values }\end{array}$ & $\begin{array}{l}\text { Cromarty } \\
2012 \\
\text { Scores }\end{array}$ & $\begin{array}{l}\text { Cromarty } \\
2015 \\
\text { Scores }\end{array}$ & $\begin{array}{l}\text { Forth } \\
2014 \\
\text { Scores }\end{array}$ & $\begin{array}{l}\text { Forth } \\
2017 / 18 \\
\text { Scores }\end{array}$ \\
\hline 1. Species composition & $80-100$ & 69.8 & 62.2 & 66.7 & 73.2 & 4 & 4 & 4 & 4 \\
\hline 2. No. of Indicator spp. & $7.2-9$ & 3 & 1 & 3 & 1 & 2 & 1 & 2 & 1 \\
\hline 3. Relative Abundance & $80-100$ & 40.9 & 30.3 & 53.3 & 50.6 & 3 & 2 & 3 & 3 \\
\hline 4. No. of species for $90 \%$ Abundance & $6.8-8.5$ & 4.8 & 8.1 & 7.3 & 4.9 & 3 & 5 & 5 & 3 \\
\hline 5. No. of Estuarine Resident (ER) spp. & $6.8-8.6$ & 8 & 10 & 8 & 7 & 5 & 5 & 5 & 5 \\
\hline 6. No. of Estuary Dependent (MS + MJ) spp. & $5.8-7.3$ & 4 & 6 & 7 & 7 & 3 & 5 & 5 & 5 \\
\hline 7. No. of Functional Guilds & $4.8-6$ & 5 & 5 & 5 & 5 & 5 & 5 & 5 & 5 \\
\hline 8. No. of Benthic Invertivore (BI) spp. & $7.3-9.1$ & 11 & 15 & 15 & 10 & 5 & 5 & 5 & 5 \\
\hline 9. No. of Piscivore (P) spp. & $5.3-6$ & 6 & 5 & 7 & 5 & 5 & 4 & 5 & 4 \\
\hline 10. No. of Feeding Guilds & $3.2-4$ & 3 & 3 & 3 & 3 & 4 & 4 & 4 & 4 \\
\hline Sum of Metric Scores & & & & & & 39 & 40 & 43 & 39 \\
\hline Environmental Quality Ratio (EQR) & & & & & & 0.725 & 0.75 & 0.825 & 0.725 \\
\hline Classification & & & & & & Good & Good & High & Good \\
\hline No. of samples & & & & & & 48 & 42 & 47 & 27 \\
\hline
\end{tabular}

Table 3. Metric values, scores and classification for TW2 (North Sea), Cromarty Firth and Forth Estuary, 2012-2018. 


\begin{tabular}{|c|c|c|c|c|c|c|c|c|c|}
\hline Metric & $\begin{array}{l}\text { Ref. Values } \\
\text { Range }\end{array}$ & $\begin{array}{l}\text { Clyde } \\
2010 / 11 \\
\text { Values }\end{array}$ & $\begin{array}{l}\text { Clyde } \\
2012 / 13 \\
\text { Values }\end{array}$ & $\begin{array}{l}\text { Clyde } \\
2016 \\
\text { Values }\end{array}$ & $\begin{array}{l}\text { Garnock } \\
2013 \\
\text { Values }\end{array}$ & $\begin{array}{l}\text { Clyde } \\
2010 / 11 \\
\text { Scores }\end{array}$ & $\begin{array}{l}\text { Clyde } \\
2012 / 13 \\
\text { Scores }\end{array}$ & $\begin{array}{l}\text { Clyde } \\
2016 \\
\text { Scores }\end{array}$ & $\begin{array}{l}\text { Garnock } \\
2013 \\
\text { Scores }\end{array}$ \\
\hline 1. Species composition & $80-100$ & 72.4 & 66.7 & 69.6 & 63.4 & 4 & 4 & 4 & 4 \\
\hline 2. No. of Indicator spp. & $7.2-9$ & 3 & 3 & 2 & 2 & 2 & 2 & 2 & 2 \\
\hline 3. Relative Abundance & $80-100$ & 47.9 & 32.3 & 50.8 & 41.0 & 3 & 2 & 3 & 3 \\
\hline 4. No. of species for $90 \%$ Abundance & $4.7-5.9$ & 6.8 & 4.3 & 4.8 & 6.0 & 5 & 4 & 5 & 5 \\
\hline 5. No. of Estuarine Resident (ER) spp. & $7.7-9.6$ & 12 & 7 & 8 & 7 & 5 & 4 & 5 & 4 \\
\hline 6. No. of Estuary Dependent (MS + MJ) spp. & $7.4-9.3$ & 9 & 8 & 6 & 5 & 5 & 5 & 4 & 3 \\
\hline 7. No. of Functional Guilds & $4.8-6$ & 6 & 6 & 5 & 4 & 5 & 5 & 5 & 4 \\
\hline 8. No. of Benthic Invertivore (BI) spp. & $11.4-14.2$ & 17 & 13 & 10 & 6 & 5 & 5 & 4 & 3 \\
\hline 9. No. of Piscivore (P) sp. & $5.2-6.6$ & 7 & 8 & 4 & 5 & 5 & 5 & 4 & 4 \\
\hline 10. No. of Feeding Guilds & $3.2-4$ & 4 & 3 & 3 & 3 & 5 & 4 & 4 & 4 \\
\hline Sum of Metric Scores & & & & & & 44 & 40 & 40 & 36 \\
\hline Environmental Quality Ratio (EQR) & & & & & & 0.85 & 0.75 & 0.75 & 0.65 \\
\hline Classification & & & & & & High & Good & Good & Good \\
\hline No. of samples & & & & & & 48 & 52 & 45 & 34 \\
\hline
\end{tabular}

Table 4. Metric values, scores and classification for TW2 (Atlantic), Clyde and Garnock/Irvine Estuaries, 2010-2016. 


\begin{tabular}{|c|c|c|c|c|c|c|c|c|c|}
\hline Metric & $\begin{array}{l}\text { Ref. Values } \\
\text { Range }\end{array}$ & $\begin{array}{l}\text { Loch Eil } \\
2012 \\
\text { Values }\end{array}$ & $\begin{array}{l}\text { Loch Eil } \\
2015 \\
\text { Values }\end{array}$ & $\begin{array}{l}\text { Gare Loch } \\
2010 \\
\text { Values }\end{array}$ & $\begin{array}{l}\text { Gare Loch } \\
2013 \\
\text { Values }\end{array}$ & $\begin{array}{l}\text { Loch Eil } \\
2012 \\
\text { Scores }\end{array}$ & $\begin{array}{l}\text { Loch Eil } \\
2015 \\
\text { Scores }\end{array}$ & $\begin{array}{l}\text { Gare Loch } \\
2010 \\
\text { Scores }\end{array}$ & $\begin{array}{l}\text { Gare Loch } \\
2013 \\
\text { Scores }\end{array}$ \\
\hline 1. Species composition & $80-100$ & 64.2 & 63.2 & 64.0 & 54.5 & 4 & 4 & 4 & 3 \\
\hline 2. No. of Indicator species & $7.2-9$ & 3 & 2 & 1 & 1 & 2 & 2 & 1 & 1 \\
\hline 3. Relative Abundance & $80-100$ & 33.2 & 40.8 & 40.4 & 45.7 & 2 & 3 & 3 & 3 \\
\hline 4. No. of species for $90 \%$ Abundance & $8.3-10.3$ & 9.8 & 11.7 & 4.2 & 5.7 & 5 & 5 & 3 & 3 \\
\hline 5. No. of Estuarine Resident (ER) species & $6.6-8.2$ & 7 & 9 & 7 & 8 & 5 & 5 & 5 & 5 \\
\hline 6. No. of Estuary Dependent (MS + MJ) species & $7.8-9.8$ & 5 & 7 & 7 & 8 & 3 & 4 & 4 & 5 \\
\hline 7. No. of Functional Guilds & $4.8-6$ & 5 & 5 & 5 & 5 & 5 & 5 & 5 & 5 \\
\hline 8. No. of Benthic Invertivore (BI) species & $16.4-20.5$ & 14 & 20 & 15 & 18 & 4 & 5 & 4 & 5 \\
\hline 9. No. of Piscivore $(P)$ species & $6-7.5$ & 8 & 6 & 4 & 5 & 5 & 4 & 3 & 4 \\
\hline 10. No. of Feeding Guilds & $3.2-4$ & 3 & 3 & 3 & 4 & 4 & 4 & 4 & 5 \\
\hline Sum of Metric Scores & & & & & & 39 & 41 & 36 & 39 \\
\hline Environmental Quality Ratio (EQR) & & & & & & 0.725 & 0.725 & 0.65 & 0.725 \\
\hline Classification & & & & & & Good & Good & Good & Good \\
\hline No. of samples & & & & & & 37 & 38 & 16 & 34 \\
\hline
\end{tabular}

Table 5. Metric values, scores and classification for TW5 (Atlantic), Loch Eil and Gare Loch, 2010 - 2015. 
In the Clyde Estuary (Fig. 3F), 189 samples landed 17,167 fish, with 41 species, and the most dominant fish were flounder $(4,470)$ and sprat $(4,420)$ accounting for $26 \%$ and $25.7 \%$ respectively of the total abundance. The next most abundant fish in the Clyde Estuary were sand goby $(1,918)$, common dab $(1,696)$, sand smelt $(1,576)$, and plaice $(1,427)$ with other common fish being pogge (326), eelpout (229), long-spined sea scorpion (Taurulus bubalis) (218), small sandeel (Ammodytes tobianus) (132), bullrout (129), cod (120) and common goby (118). Concealed within the data is the occasional serendipitous capture of fish shoals with nearly $80 \%$ of the total sprat catch derived from just two beach seine samples in 2013 and $67 \%$ of the total sand smelt from just two beach seine samples in 2016. Migratory species recorded included small numbers of European eel (30), salmon (17), and sea trout (9). Some species such as greater pipefish (Syngnathus acus), red gurnard (Chelidonichthys cuculus), goldsinny wrasse (Ctenolabrus rupestris), snake blenny (Lumpenus lampretaeformis), spotted dragonet (Callionymus maculatus), and roach (Rutilus rutilus) are represented in the Clyde Estuary by only single specimens.

In the Garnock Estuary (Fig. 3G), 51 samples landed 1,520 fish, with 25 species, of which the most abundant was the sand goby (872), which accounted for $57 \%$ of the total abundance. All but one of these sand gobies were captured in two (of the six) sampling years due to the introduction of the beach seining method. Other common species included flounder (180), plaice (113), and pollack (92). Migratory species recorded included small numbers of European eel (9), and sea trout (3). In 2010, a single perch (Perca fluviatilis) and single minnow (Phoxinus phoxinus) were captured, presumably due to high river flows at the time. It might seem likely that the small size of the Garnock Estuary, compared with the Clyde Estuary, would explain its lower species diversity but the Clyde Estuary survey of 2012/13 with a similar number of samples (52), shows a similar number of species (25), and has a fairly similar abundance $(1,878)$, if the shoal of 3,887 sprat is excluded.

For TW5 sea lochs on the west coast (Atlantic Ecoregion) the surveys, with 171 samples, have landed 5,970 fish with 49 species (Supplementary File 4). Although Loch Eil and Gare Loch are of similar size, and harbour the same number of species, the total catch in Gare Loch is over five times that of Loch Eil despite the latter having a greater sampling effort. The dominant fish also appear to be quite different in the two lochs.

For Loch Eil (Fig. 3H), 95 samples landed 1,125 fish for 38 species. The most abundant fish were two-spotted goby (221), common dab (209), poor cod (Trisopterus minutus) (120), and 15-spined stickleback (Spinachia spinachia) (115), with smaller numbers of whiting (76), common dragonet (Callionymus lyra) (53), cod (49), and long rough dab (Hippoglossoides platessoides) (47). Of these the two-spotted goby was only found in Loch Eil. Migratory species encountered included European eel (40), salmon (1), and sea trout (40). A wide variety of other species was captured in smaller numbers including eight found only in Loch Eil: great spotted dogfish (Scyliorhinus stellaris) (1), thornback ray (Raja clavata) (2), skate (Dipturus batis) (1), blue whiting (Micromesistius poutassou) (1), three-spined stickleback (13), red gurnard (3), corkwing wrasse (Symphodus melops) (4), and reticulated dragonet (Callionymus reticulatus) (5). In Loch Eil three different species of dragonet were recorded. Females of the spotted and the reticulated dragonets can be quite difficult to distinguish.

For Gare Loch (Fig. 3F), 76 samples landed 5,970 fish for 38 species. The most abundant fish were common dab (2,712), plaice (786), long rough dab (613), and sand goby (253). Other common fish included cod (73), common dragonet (67), common sole (61), and flounder (51). The only migratory species present were sea trout (7). Five species were recorded exclusively from Gare Loch; Nilsson's pipefish (Syngnathus rostellatus) (1), thicklip grey mullet (3), shanny (Lipophrys pholis) (1), snake blenny (16), Fries's goby (Lesueurigobius friesii) (2), and solenette (Buglossidium luteum) (9). The Fries's goby is associated with the burrows of Norway lobsters (Nephrops norvegicus), which occur in the deeper parts of the loch. Note that four of the TW5 Reference species spurdog (Squalus acanthias), herring, mackerel, Norway pout (Trisopterus esmarkii) - were not captured in any of the SEPA surveys in TW5 waters.

\section{Classification assessments}

The TFCI tool was applied to the full set of SEPA data from 2005 to 2018. The Ecological Quality Ratio (EQR) and the WFD class, are shown for all years in Supplementary Files 2, 3 and 4 but only those surveys in later years, where a sufficient number of samples has been collected across the whole estuary using the full suite of sampling methods, should be regarded as valid. For these latter surveys further details of the individual metric values, compared with the reference condition range of values, are shown in Tables 3,4 , and 5 . The Forth 2017/18 sampling is also included here for comparison, even though the numbers of samples recovered fell just below the minimum required.

\section{DISCUSSION}

SEPA's approach to monitoring and classification of TW fish communities has evolved over the years. Previously, sampling of estuarine fish was more limited in scope with only two main transitional waters monitored, with fewer methods and less spatial coverage. The former ADRIS estuary classification scheme included only three classification levels $(\mathrm{A} / \mathrm{B}, \mathrm{C}$, and $\mathrm{D})$ for the migratory and resident fish and these were based on relatively simple qualitative factors (ADRIS, 1994). For Class A or B (Excellent or Good) the water quality allowed free passage of migratory fish and the resident fish community was normal. For Class C (Unsatisfactory) the water quality caused some restriction on the passage of migratory fish and the resident fish community was modified. For Class D (Seriously Polluted) passage of migratory fish was wholly prevented and the resident fish community 
impoverished. Discrimination between classes A and B was determined by other water quality measures including dissolved oxygen and persistent pollutant levels.

Under ADRIS the focus was on water quality assessment, with some support from qualitative biological monitoring. However, under WFD, the emphasis has been on ecological community assessment, with some support from water quality monitoring. The WFD classification for TW Fish utilises new analysis tools and semi-quantitative methods. Preliminary WFD sampling for transitional fish commenced in 2005 with a view to running provisional classifications from 2007. Some of the transitional waters initially investigated (Dornoch and Beauly/Moray Firths, and Tay Estuary) were subsequently dropped from the list of tentative representative waters. Early attempts to utilise mid-water pelagic trawls as one of the sampling methods were later abandoned, as recommended by the UKTAG TW Fish Task Team, as these nets proved difficult to deploy in the confined spaces of estuaries and the catch data were of limited value. While a multimethod approach, using beam trawls, fyke nets and beach seines, was eventually settled upon, it was some considerable time before this was introduced to the sampling programme for each of the representative surveillance waters (see Table 2). The use of the minibeam trawl which could be operated in shallower waters from a RIB did not take place until 2012. The use of fyke nets staked in the intertidal was found to have some drawbacks. To ensure the fyke trap-ends remained covered with water at all times, the nets had to be set in the shallows around the time of low water. The nets were then left for a 12-hour tidal cycle. To avoid unauthorised access, or theft, of the nets the setting time had to be close to nightfall so the nets would be quickly concealed, and the nets recovered early the next morning on the falling tide. From 2014, the deployment method changed with the nets still set around low water but dropped in the shallow sublittoral zone from small boats. These fykes were fixed by small anchors and marked by pellet buoys. As the nets were already fully submerged at the time of deployment, they were inaccessible from the shore and there was much more flexibility regarding the deployment times. However, this meant that they were always set in deeper water compared with previous settings just below the low tide level.

It had been initially envisaged that the six representative transitional waters in Scotland might be surveyed and assessed on an annual basis, but with many other demands on SEPA's boat crew and scientific staff, this proved too ambitious to fit into SEPA's busy work programme. A revised plan to sample each transitional water every third year was proposed, allowing two assessments within the standard WFD six-year reporting cycle. However, even this proved difficult at times and compromises had to be made. Initially both spring and autumn sampling was undertaken, as recommended in the UKTAG guidance, but it proved easier to timetable all the sampling into an intensive autumn schedule as permitted by UKTAG. However, this had inherent risks if some of the sampling was missed due to poor weather and could not be repeated before the autumn sampling window expired. In fact, for some estuaries, only part of the estuary was sampled one year with the remainder sampled the following year and the data combined and assessed as if collected in a single year (e.g. Clyde 2010/11, Clyde 2012/13, Forth 2017/18). Other planned surveys were cancelled due to lack of appropriate vessels within the required sampling windows. From 2016, SEPA's focus for marine monitoring switched almost entirely towards the aquaculture sector with WFD fish monitoring being de-prioritised and no TW fish sampling has been undertaken since 2018 .

Although provisional classifications were attempted, the application of the TFCI remained invalid until the determination of reference conditions for each transitional water type was finalised. This required the collation of reference datasets, including comparative datasets derived from a multi-method sampling approach, from Scotland, north-east England and Northern Ireland. The reference conditions for western Scotland (Atlantic Ecoregion) were completed in 2012 and those for eastern Scotland (North Sea Ecoregion) completed in 2014. This finally enabled proper classifications to be undertaken and the TFCI could also be applied to the previous sampling data back to 2005, with the caveat that only those assessments with sufficient samples (i.e. >30), which utilise multi-method data collected from throughout the representative transitional water, should be regarded as fully valid. Hence, many of the EQR and classification results shown in Supplementary Files 2-4 do not fully meet these criteria and should be viewed with some caution. Only those EQR results shown in more detail in Tables 3-5 (excluding Forth 2017/18) are of acceptable confidence.

The introduction of multi-method sampling, corresponding with additional sampling sites, appears to have added new species to the monitoring tallies in some of the water bodies, pointing to the efficacy of this approach. For the Clyde Estuary the broadened sampling regime introduced in 2010 appears to add European eel (30), salmon (17), sea trout (9), sand-smelt $(1,576)$, three-spined stickleback $(55)$, and perhaps a few other species in smaller numbers, as well as elevated abundances of sprat and small sandeel. Sampling in upper reaches of the Clyde Estuary also added a few freshwater stragglers such as perch, roach, and minnow. Similarly, in the Garnock Estuary from 2010 a new sampling regime adds several new species and elevated abundances, mostly from the use of beach seines. However, the appearance of the common goby in 2010 in both estuaries is probably is due to this species being previously overlooked and an improved ability, following NMBAQC workshops, to distinguish this species from the sand goby.

For TW5 (Atlantic) sea lochs the introduction of the multi-method approach, with new sampling sites in Gare Loch in 2010 appears to have resulted in catches of ten 
new species: sea trout (7), pollack (6), saithe (3), hake (1), sand smelt (16), 15-spined stickleback (7), Nilsson's pipefish (1), long-spined sea scorpion (5), thicklip grey mullet (3), and shanny (1). In Loch Eil, only beam trawl samples were used between 2005 and 2009 and the catch abundances were very low. Significantly elevated abundances and 22 new species were added after the extended sampling regime commenced in Loch Eil in 2012.

The fish communities of the three types, TW2 (North Sea), TW2 (Atlantic), and TW5 (Atlantic) show a variety of differences in their species compositions. The differences between TW2 (Atlantic) and TW5 (Atlantic) may be partly blurred by the physical connection between Gare Loch and the Clyde Estuary. Although the east and west coasts of Scotland are designated as different ecoregions under WFD there is no obvious and consistent difference of fish species between east and west. Only the east coast has catches of river lampreys or smelt, but these are also known to occur on the west coast, even if not captured in the SEPA WFD surveys. The sand smelt, which superficially resembles smelt (but is not closely related), was frequently captured on the west coast but is not recorded in the SEPA east coast surveys, although its presence in the Forth is indicated within the east coast reference conditions. The addition of new species cited above in relation to a broadened sampling regime may be due in part to simply collecting more samples. Ideally, to gain a representative sampling of a water body, sampling should be continued, by whatever methods, until no further new species are added. Hence a rarefaction curve of the cumulative number of species captured against the number of samples would gradually flatten out as the number of species peaks and few or no new species are added. Investigations by the UKTAG TW Fish Task Team indicated that such curves usually begin to flatten after around 30 samples, so survey plans usually set this as a minimum number of samples and have generally capped the planned number of samples at 50 . While continued sampling thereafter may find the occasional rare species, the effect on the individual metrics and the overall assessment is likely to be negligible. Long term historical records suggest that continued recording will continue to add rarer Marine Adventitious (MA) species such as the extremely rare vagrant swordfish already mentioned.

For TW2 estuaries (North Sea) only the Cromarty Firth 2012, 2015, and Forth Estuary 2014 fully meet the aspirations of a multi-method approach with sufficient sample numbers and geographical spread of the sampling effort. The Forth Estuary survey in 2008 used four methods but (1) only collected a single fyke and single seine sample, (2) in 2009 only two methods were used, and (3) in 2011 no sampling took place in the upper estuary. In 2017/18 the Forth Estuary sampling fell just short of the minimum number of samples due to bad weather and gear damage, but details of this assessment are included here as a comparison for the 2014 survey. For TW2 estuaries (Atlantic) the sampling only fully met the requirements in the Clyde Estuary
2010/11, 2012/13, 2016 and the Garnock Estuary in 2013, and for TW5 (Atlantic) sea lochs only Loch Eil in 2012, 2015 and Gare Loch in 2013. These WFD classification results indicate that the fish communities in Scotland's representative transitional waters are currently in Good or High ecological status, at least for the fish biological quality element. The reduction in sampling effort in the Forth Estuary in 2017/18, to below the recommended minimum, appears to cause the class to drop from High to Good. This indicates that reduced sampling effort may result in false class downgrades. The importance of gaining enough samples to ensure confidence in the classification results cannot be overemphasized.

A closer look at the individual metric values compared with the upper and lower boundaries for reference conditions provides more information on the fish communities. This is shown for the valid assessments highlighted above, along with a couple of examples, Gare Loch 2010, and Forth Estuary 2017/18, where the number of samples was insufficient (Tables 3-5). The upper reference boundary value is divided into five equal bands (quintiles) to give boundaries for the metric scores 1 to 5 , with band 5 being equivalent to the reference condition boundaries. Few of the metric value boundaries end up being whole numbers yet most of the metric values measured can only be whole numbers, so in practice the lower metric value boundaries often have to be rounded up to the next whole number. For the number of indicator species, for example, the lower reference boundary is a metric value of 7.2 (i.e. the maximum value 9 minus a fifth of the maximum value, 1.8). Thus in practice six or seven indicator species will have a metric score of 4 , and eight or nine indicator species will achieve a metric score of 5 .

The reduction in the number of samples for the Forth Estuary in 2017/18 compared with 2014 affected the scores for Metrics 2, 4, and 9, and brought the classification down from High to Good (Table 3). For Gare Loch 2010, doubling the number of samples in Gare Loch 2013 increased scores for Metrics 6, 8, 9, and 10 with a decrease for Metric 1 score. Although the EQR increased, the classification remained within Good (Table 5).

The results suggest it would be beneficial to further investigate the possible effect of the number of samples collected on the actual EQR scores and perhaps up the threshold for the acceptable number of samples. However, in the data here it is difficult to disentangle the effects of number of samples from the effects of introducing new sampling methods as shown in Table 2. Comparing the reference condition value range with the recorded values for each metric casts some light on which metrics have most influence on the overall EQR.

For Metric 1, the species composition, similarity value ranges were similar for each water body type, mostly between 60 and $80 \%$, with none attaining the reference condition range of $80-100 \%$. For Metric 3, the relative abundance, similarity ranges were all much lower, 
within the $30-60 \%$ range. The inherent complexity and variability of fish communities with respect to species composition and relative abundances perhaps makes it more difficult to achieve a close match to the defined reference conditions for these metrics.

For Metric 4, the number of species making up $90 \%$ of the abundance, the recorded metric value range between four and 11 species was broadly the same for each type and for TW2 (Atlantic) and TW5 (Atlantic) actually exceeded the upper reference condition boundary in some cases, suggesting that the upper boundary ought to be reviewed. For Metric 5, the number of Estuarine Resident (ER) species, the recorded metric value range was 7 to 12 , mostly within the reference condition boundaries but also again exceeded the upper boundary in some cases. For Metric 6, the number of estuary dependent species (Marine Seasonals (MS) and Marine Juveniles (MJ)), the metric value range at 4 to 9 , was relatively broad and frequently within the reference condition boundaries.

Metrics 7 and 10 (functional and feeding guild composition) showed little variation in metric values. There were no catches from the freshwater (FW) functional guild in TW2 (North Sea), TW5 (Atlantic), or in the Garnock/Irvine Estuary 2013 and Clyde Estuary 2016, both TW2 (Atlantic). This may have been due to insufficient sampling in the upper (reduced salinity) reaches of these water bodies. It should be noted that the three-spined stickleback which is often captured in these transitional waters is categorised as an anadromous species (CA guild) rather than a freshwater one. Of the four feeding guilds the maximum metric value of 4 was only occasionally reduced due to the absence of detritivores (D), which are represented here solely by thicklip grey mullet.

For Metric 8, the number of benthic invertivores (BI), the metric value range for TW2 (North Sea) was 10 to 15 , all above the upper reference condition boundary, for TW2 (Atlantic) the range, 6 to 17, was broader and again exceeded the reference upper boundary, while for TW5 (Atlantic), the range, 15 to 20, was mostly within the reference condition boundaries. For metric 9, the number of piscivores $(\mathrm{P})$, the range 4 to 8 , was fairly similar for all of the water body types and bridged the boundaries of the reference conditions.

For Metric 2, the number of indicator species, the metric value range across all water body types was 1 to 3 , and this metric showed the greatest disparity from the reference condition boundaries with none of waters bodies recording anywhere near even the lower reference condition boundary value of 7.2 indicator species. This metric has some notable limitations in that the indicator species may be under-represented if actual sampling times mismatch the different migratory periods of the different indicator species. Indeed, there appears to be a sampling bias against the indicator species as catches of most migratory species are generally small with many seemingly absent, yet it is known from upstream fishery catches that some species, such as salmon and sea trout, run up into rivers that feed into most of the representative transitional waters (FRS, 2007, Marine Scotland, 2019). Similarly, for the lampreys, while only a few river lampreys were captured from the Forth Estuary, other investigations in upstream fresh waters indicate the occurrence of both river and sea lampreys in tributary rivers of the representative transitional waters (Ecological Research Associates, 2005; O'Reilly et al., 2016; O'Reilly \& Morrison, 2018) which must have made migratory passage through the respective transitional water. The TFCI only permits inclusion of data collected from the actual surveyed transitional water. Were such upstream fishery information on the presence of salmonids or lampreys to be incorporated into the TFCI, then the Metric 2 scores could change significantly with a consequent change to the final classification result.

Another shortcoming of Metric 2 is that the presence alone of indicator species does not provide a full picture of the ecological status of these important species. Other studies show that migratory fish in particular may be in real decline due to pressures outwith the transitional water - either upstream in the freshwaters or in coastal or offshore marine waters during their migrations (Malcolm et al., 2010). Both salmon and sea trout, for example, are known to be in decline throughout Scotland and it is suspected that factors affecting their growth and survival at sea may be an important contributor (Ashley, 2019; Kettle-White, 2018; Middlemas, 2019; Reynolds, 2004; Todd et al., 2008; Todd, 2014).

Lamprey populations are less well studied than those of salmonids, but both sea lamprey and river lamprey also appear to have suffered declines in Scotland, although the river lamprey is now considered to have recovered significantly (Maitland et al., 2015; Hume, 2018). There has also been a drastic decline of the European eel populations throughout the whole of Europe, with young glass eel recruitment falling by more than $90 \%$ in the 1980s. The European Commission has initiated an Eel Recovery Plan (Bevaqua et al., 2009) to try to return the European eel stock to more sustainable levels and an Eel Management Plan has been produced for Scotland (DEFRA, 2010). Whilst riverine eels are subject to human pressures including overfishing, habitat destruction, migration barriers such as weirs or invasive swim-bladder parasites, recent modelling studies have suggested that ocean current dynamics in the North Atlantic may have caused the major recruitment failures in Europe (Eizaguirre \& Baltazar-Soares, 2014; Baltazar-Soares et al., 2014).

Other indicator species such as the smelt (or sparling) and the allis and twaite shads, which may have been relatively widespread in historical times, now have only very limited distributions in Scotland. The smelt is presently restricted to the Tay, Forth and Cree estuaries (Maitland \& Lyle, 1996) and the shads to the Solway Firth region (Maitland \& Lyle, 2005). Finally, the European sturgeon is included as an indicator species, although it is critically endangered with only a small 
population clinging on in the Gironde basin in southwest France (Council of Europe, 2018) and only the very occasional vagrant turns up in British waters. This sturgeon may have spawned in the Severn and Thames in historical times, but it is uncertain if it ever spawned in Scottish waters.

A new tool for assessing transitional water fish communities, the Estuarine Multi-metric Fish Index (EMFI), was developed by Kelly \& Harrison (2013) based on their studies of fish communities throughout Ireland. The EMFI is similar to the TFCI in that it is a multi-metric tool that assesses the four community characteristics: species diversity/composition, species abundance, estuarine utilisation, and trophic integrity and also compares metric values against defined reference conditions. However, it incorporates 14 metrics, including the relative abundances of estuarine residents, marine migrants, zoobenthivores, and piscivores. The investigations by Harrison \& Kelly (2013) found a relationship between species richness and estuary size, so estuaries are categorised by their size and the various species richness scores adjusted accordingly. The tool also includes a metric for the number of introduced species, which in Ireland could include freshwater fish such as dace (Leuciscus leuciscus), chub (Squalius cephalus) and roach entering the upper reaches of estuaries. Similar introduced freshwater species also occur in Scotland, but in recent years there has also been records of non-native Pacific pink salmon (Oncorhynchus gorbuscha) passing through some of Scotland's estuaries and up into its rivers (BBC, 2019). A practitioner's guide for the application of the EMFI was issued by WFD-UKTAG (2014b) and the tool has now been intercalibrated (Lepage et al., 2016; Harrison et al., 2018; European Commission, 2018). The EMFI appears to offer an improved assessment tool and it would clearly be beneficial to test it on the Scottish data and derive new EMFI Scottish reference conditions with the aim of introducing it to Scotland for future monitoring.

It is unfortunate that political upheaval in the U.K. has changed priorities and cast some doubt over the long term commitment to the standards and monitoring requirements of the EU Water Framework Directive. Nevertheless, the directive sparked the production of the first proper semi-quantitative assessment tools for transitional water fish in the U.K. and Ireland, which are also comparable with similar tools elsewhere in Europe. A set of reference conditions for Scottish transitional water fish communities was derived for the first time. Whilst the assessment tools may be subject to some refinement, or review of their reference condition baselines, they will continue to provide an effective approach for monitoring change in transitional water fish communities, whether due to local anthropogenic factors or perhaps also long term impacts from climate change.

\section{ACKNOWLEDGEMENTS}

Thanks are due to the crews of the SEPA survey vessel Sir John Murray and the Marine Scotland survey vessel
Alba na Mara for undertaking various sampling operations. Numerous scientists have assisted with field surveys over many years including Marie Russell (Marine Science, Scotland) and SEPA marine ecologists Lex Pearce, Kirsty Allen, Shelley Reid, Laura Bush, Adrian Moore, Nick Cross, Ryan Eustace, and Emma Priestley. Colleagues on the UK-WFD Transitional Waters Fish Task Team, including Steve Coates and Adam Waugh (both Environment Agency, England), and Trevor Harrison (DAERA, Northern Ireland), have provided valuable guidance on sampling methods and strategies.

\section{REFERENCES}

ADRIS (1994). ADRIS Estuary Classification Scheme, 1994. Association of Directors and River Inspectors for Scotland. Internal document produced for the River Purification Boards of Scotland and adopted by SEPA in 1996.

Angus, S. (2016). Scottish saline lagoons: Impacts and challenges of climate change. Estuarine Coastal and Shelf Science 198. https://doi.org/10.1016/j.ecss.2016.07.014

Ashley, K. (2019). Wild Salmon. Scottish Parliament Information Centre briefing, SB 19-48. https://digitalpublications.parliament.scot/Research Briefings/Report/2019/8/19/Wild-Salmon Accessed 10th November 2020.

Baltazar-Soares, M., Biastoch, A., Harrod, C., Hanel, R., Marohn, L., Prigge, E. et al. (2014). Recruitment collapse and population structure of the European Eel shaped by local ocean current dynamics. Current Biology 24, 104-108. https://doi.org/10.1016/j.cub.2013.11.031

BBC (2009). Swordfish find shocks Alloa fisherman. http:/news.bbc.co.uk/1/hi/Scotland/Tayside and central/8292805.stm

BBC (2019). Invasive Pacific pink salmon found in Scottish rivers.

https://www.bbc.co.uk/news/uk-scotland-

highlands-islands-49482634 Accessed 10th November 2020.

Bevaqua, D., Melia, P., Crivelli, A., Gatto, M., De Leo, G.A. (2009). Assessing management plans for the recovery of the European Eel: A need for multiobjective analysis. American Fisheries Society Symposium 69, 637-647.

Coates, S.A., Colclough, S.R., Robson, M. \& Harrison, T.D. (2004). Development of an Estuarine Classification Scheme for the Water Framework Directive. Phase 1 \& 2 - Transitional Fish Component. R\&D Technical Report E1-131/TR. Environment Agency, Bristol.

Coates, S., Waugh, A., Anwar, A. \& Robson, M. (2007). Efficacy of a multi-metric fish index as an analysis tool for the transitional fish component of the Water Framework Directive. Marine Pollution Bulletin 55, 225-240. https://doi.org/10.1016/j.marpolbul.2006.08.029

Council of Europe (2018). Pan-European Action Plan for Sturgeons. Prepared by the World Sturgeon Conservation Society and WWF. Convention on the Conservation of European Wildlife and Natural 
Habitats. Standing Committee, 38th meeting, Strasbourg, 27-30 November 2018, TVPS/Inf(2018)6. https://rm.coe.int/pan-europeanaction-plan-for-sturgeons/16808e84f3 Accessed 10th November 2020.

DEFRA (2010). Eel Management Plans for the United Kingdom. Scotland River Basin District. Department for the Environment, Food and Rural Affairs. www.gov.scot/publications/eel-management-plan

Edwards, A. \& Sharples, F. (1986). Scottish Sea Lochs: A Catalogue. Scottish Marine Biological Association, Dunstaffnage Marine Research Laboratory.

Edwards, R. (1989). Lone sparling brings Forth hope. Scotland on Sunday, 10th September.

Eizaguirre, C. \& Baltazar-Soares, M. (2014). Rise and fall of eel numbers linked to ocean currents. The Conversation, 16th Jan.

https://theconversation.com/rise-and-fall-of-eelnumbers-linked-to-ocean-currents-21869 Accessed 10th November 2020.

Elliott, M. \& Dewailly, F. (1995). The structure and components of European estuarine fish assemblages. Netherlands Journal of Aquatic Ecology 29, 397417. https://doi.org/10.1007/BF02084239

Elliott, M. \& Griffiths, A.H. (1986). Mercury contamination in components of an estuarine ecosystem. Water Science and Technology 18, 161170.

https://doi.org/10.2166/wst.1986.0192

Elliott, M. \& Griffiths, A.H. (1987). Contamination and effects of hydrocarbons on the Forth ecosystem, Scotland. Proceedings of the Royal Society of Edinburgh 93B, 327-342. https://doi.org/10.1017/S0269727000006783

Elliott, M., Griffiths, A.H. \& Taylor, C.J.L. (1988). The role of fish studies in estuarine pollution assessment. Journal of Fish Biology 33A, 51-61. https://doi.org/10.1111/j.1095-8649.1988.tb05558.x

Elliott, M. \& Hemingway, K. (2002). Fishes in Estuaries. Blackwell Science Ltd., Oxford. https://doi.org/10.1002/9780470995228

Elliott, M., O’Reilly, M.G. \& Taylor, C.J.L. (1990). The Forth Estuary: a nursery and overwintering area for North Sea fishes. Hydrobiologia, 195, 89-103. https://doi.org/10.1007/BF00026816

Elliott, M. \& Taylor, C.J.L. (1989). The structure and functioning of an estuarine/marine fish community in the Forth estuary, Scotland. Proceedings of the 21st European Marine Biology Symposium, Gdansk, 14-19 September 1986, 227-240.

Elliott, M., Whitfield, A.K., Potter, I.C., Blaber, S.J.M., Cyrus, D.P., Nordlie, F.G. \& Harrison, T.D. (2007). The guild approach to categorizing estuarine fish assemblages: a global review. Fish and Fisheries 8, 241-268.

Ecological Research Associates (2005). National Lamprey Survey of Scotland. Report to Scottish Natural Heritage, (ROAME No. F02AC602).

European Commission (2013). Commission Decision (2013/480/EC) of 20 September 2013 establishing, pursuant to Directive 2000/60/EC of the European
Parliament and of the Council, the values of the Member State monitoring system classifications as a result of the intercalibration exercise and repealing Decision 2008/915/EC. Official Journal of the European Union, L 266/1. https://eurlex.europa.eu/legalcontent/EN/TXT/PDF/?uri=CELEX:32013D0480\& qid $=1589479209675 \&$ from $=E N$ Accessed 6th June 2020.

European Commission (2018). Commission Decision (EU) 2018/229 of 12 February 2018 establishing, pursuant to Directive 2000/60/EC of the European Parliament and of the Council, the values of the Member State monitoring system classifications as a result of the intercalibration exercise and repealing Commission Decision 2013/480/EU. Official Journal of the European Union, L 47/1. https://eurlex.europa.eu/legalcontent/EN/TXT/?qid=1589479209675\&uri=CELE X:32018D0229 Accessed 6th June 2020.

European Union (2000). Parliament and Council Directive 2000/60/EC of 23rd October 2000. Establishing a Framework for Community Action in the Field of Water Policy. Official Journal PECONS 3639/1/00 REV 1. Brussels: European Union.

Franco, A., Elliott, M., Franzoi, P. \& Torricelli, P. (2008). Life strategies of fish in European estuaries: the functional guild approach. Marine Ecology Progress Series 354-219-228. https://doi.org/10.3354/meps07203

FRS (2003). Decline \& Recovery of Salmon in the Central Belt of Scotland. Fisheries Research Services, FRS Freshwater Laboratory, Pitlochry,. https://www2.gov.scot/Uploads/Documents/Decline \%20poster.pdf Accessed 10th November 2020.

FRS (2007). Statistical Bulletin. Scottish Salmon and Sea Trout catches, 2006. Fisheries Series, No. Fis/2007/1, September 2007. Fisheries Research Services, FRS Freshwater Laboratory, Pitlochry.

Gardiner, R. \& Armstrong, J. (1996). Migratory Salmonid Fishes in the River Kelvin: Historical Backgound, Present Situation and Opportunities for Improvement. Fisheries Research Services Report, 4/96.

Greenstreet, S.P.R., Rossberg, A.G., Fox, C.J., Le Quesne, W.J.F., Blasdale, T., Boulcott, P. et al. (2012). Demersal fish biodiversity: species-level indicators and trends-based targets for the Marine Strategy Framework Directive. ICES Journal of Marine Science 69, 1789-1801. https://doi.org/10.1093/icesjms/fss 148

Greenwood, M.F.D. (2008a). Trawls and cooling water intakes as estuarine sampling tools: trends in relative abundance and length selectivity. Estuarine, Coastal and Shelf Science 76, 121-130. https://doi.org/10.1016/j.ecss.2007.06.008

Greenwood, M.F.D. (2008b). Fish mortality by impingement on intake screens of Britain's largest direct-cooled power station. Marine Pollution Bulletin 56, 723-739. https://doi.org/10.1016/j.marpolbul.2007.12.008

Greenwood, M.F.D., Hill, A.S. \& McLusky, D. (2002). Trends in abundance of demersal fish populations of 
the lower Forth Estuary, Scotland from 1982-2001. Journal of Fish Biology 61A, 90-104. https://doi.org/10.1006/jfbi.2002.2070

Greenwood, M.F.D. \& Hill, A.S. (2003). Temporal, spatial and tidal influences on demersal fish abundance in the Forth Estuary. Estuarine, Coastal and Shelf Science 58, 211-225.

https://doi.org/10.1016/S0272-7714(03)00071-4

Greenwood, M.F.D. \& Maitland, P.S. (2009). Longterm changes in fish-assemblage composition from cooling-water intake screens in the Forth Estuary, Scotland, UK. JMBA2 - Biodiversity Records, 2, Jan.2009, e8. https://doi.org/10.1017/S1755267208000080

Griffiths, A.H. (1987). Water Quality of the estuary and Firth of Forth, Scotland. Proceedings of the Royal Society of Edinburgh 93B, 303-314. https://doi.org/10.1017/S026972700000676X

Haig, A.J.N. (1986). Use of the Clyde Estuary and Firth for disposal of effluents. Proceedings of the Royal Society of Edinburgh 90B, 393-405. https://doi.org/10.1017/S026972700000511X

Hammerton, D. (1986). Cleaning the Clyde - a century of progress? Journal of the Operational Research Society 37, 911-921. https://doi.org/10.1057/jors.1986.154

Hammerton, D. (1997). The restoration of the Clyde River. In: Laenen, A. \& Dunnette, D.A. (Editors). River Quality - Dynamics and Restoration, pp. 423434. CRC Press, Boca Raton, Florida, U.S.A. https://doi.org/10.1201/9780203740576-39

Harrison, T.D. \& Kelly, F.L. (2013). Development of an estuarine multi-metric fish index and its application to Irish transitional waters. Ecological Indicators 34, 494-506. https://doi.org/10.1016/j.ecolind.2013.06.018

Harrison, T., Kelly, F., Lepage, M. \& Sales Herrero, F. (2018). Intercalibration of a New Fish Ecological Assessment Method. Transitional Waters North East Atlantic Geographical Intercalibration Group, JRC Technical Reports, European Commission. https://publications.jrc.ec.europa.eu/repository/bitst ream/JRC115083/jrc115083_tw_neagig._fish_ecol ogical_assesment_methods-new_method-1.pdf Accessed 10th November 2020.

Henderson, A.R. \& Hamilton, J.D. (1986). The status of fish populations in the Clyde Estuary. Proceedings of the Royal Society of Edinburgh 90B, 157-170. https://doi.org/10.1017/S0269727000004966

Hume, J.B. (2018). A review of the geographic distribution, status and conservation of Scotland's lampreys. The Glasgow Naturalist 26(4), 67-76.

Kettle-White, A. (2018). Turning the Tide for Scotland's Sea Trout.

https://scottishwildlifetrust.org.uk/2018/12/turningthe-tide-for-scotlands-sea-trout/ Accessed 10th November 2020.

Leatherland, T.M. (1987). The estuary and Firth of Forth, Scotland: uses and aims. Proceedings of the Royal Society of Edinburgh 93B, 285-297. https://doi.org/10.1017/S0269727000006746

Lepage, M., Briene, J., Van den Bergh, E., Mosch, E.C., Scholle, J., Kelly, F. et al. (2013). Intercalibration of
Biological Elements for Transitional and Coastal Water Bodies. North East Atlantic GIG: Transitional Waters - Fish. European Commission Intercalibration Technical Report.

Lepage, M., Harrison, T., Breine, J., Cabral, H., Coates, S., Galván, C. et al. (2016). An approach to intercalibrate ecological classification tools using fish in transitional water of the North East Atlantic. Ecological Indicators 67, 318-327. https://doi.org/10.1016/j.ecolind.2016.02.055

Mackay, D.W., Tayler, W.K. \& Henderson, A.R. (1978). The recovery of the polluted Clyde Estuary. Proceedings of the Royal Society of Edinburgh 76B, 135-152. https://doi.org/10.1017/S0269727000002839

Mackay, D.W. \& Doughty, C.R. (1986). Migratory salmonids of the Estuary and Firth of Clyde. Proceedings of the Royal Society of Edinburgh 90B, 479-490. https://doi.org/10.1017/S0269727000005170

Maitland, P.S. \& Herdson, D. (2009). Key to the Marine and Freshwater Fishes of Britain and Ireland. Environment Agency, Bristol.

Maitland, P.S. \& Lyle, A.A. (1990). Conservation of Sparling and other fish in Scotland. Journal of the Edinburgh Natural History Society 1-2, 16-18.

Maitland, P.S. \& Lyle, A.A. (1996). The smelt Osmerus eperlanus in Scotland. Freshwater Forum 6, 57-68.

Maitland, P.S. \& Lyle, A.A. (2005). Ecology of Allis shad Alosa alosa and Twaite shad Alosa fallax in the Solway Firth, Scotland. Hydrobiologia 534, 205221. https://doi.org/10.1007/s10750-004-1571-1

Maitland, P.S., Renaud, C.R., Quintella, B.R., Close, D.A. \& Docker, M.F. (2015). Conservation of native lampreys. In: Docker, M.F. (Editor). Lampreys: Biology, Conservation and Control. Vol. 1, pp. 376428. Springer Publishing, New York, U.S.A. https://doi.org/10.1007/978-94-017-9306-3_8

Malcolm, I.A., Godfrey, J. \& Youngson, A.F. (2010). Review of migratory routes and behaviour of Atlantic Salmon, Sea Trout, and European Eel in Scotland's coastal environment: Implications for the development of marine renewables. Scottish Marine and Freshwater Science 1(14), 1-77.

Marine Scotland (2019). Salmon and Sea Trout Fishery Statistics: 2018 Season - Reported Catch and Effort by Method. DOI: 10.4789/12206-1. Retrieved from https://scotland.shinyapps.io/sg-salmon-sea-troutcatch/ Accessed 10th November 2020

McInerny, C.J. \& Hoey, K. (2021). Unusual aquatic vertebrates in the Firth of Forth, Scotland, during 2020: swordfish and northern bottlenose whales. The Glasgow Naturalist 27(3), 97-98. https://doi.org/10.37208/tgn27308

McLusky, D.S. (1987). The Natural Environment of the Estuary and Firth of Forth. Introduction. Proceedings of the Royal Society of Edinburgh 93B, vii-x. https://doi.org/10.1017/S0269727000006837

Middlemas, S. (2019). Understanding the decline of Atlantic salmon catches in Scotland. British Ecological Society/News and Opinion, 
https://www.britishecologicalsociety.org/understan ding-decline-atlantic-salmon-catches-scotland/ Accessed 10th November 2020.

O'Reilly, M., Nowacki, S. \& Elliott, M. (2016). A Citizen Science approach to monitoring migratory lampreys under the Water Framework Directive, with some new accounts of sea lampreys (Petromyzon marinus) from south west Scotland. The Glasgow Naturalist 26(2), 102-105.

O'Reilly, M. \& Morrison, S. (2018). First record of river lampreys (Lampetra fluviatilis) in the River Garnock, Ayrshire. The Glasgow Naturalist 26(4), 92-93.

Pomfret, J.R., Elliott, M., O’Reilly, M.G. \& Phillips, S. (1991). Spatial and temporal patterns in the fish communities in two UK North Sea estuaries. In: Elliott, M. \& Ducrotoy, J.P. (Editors). ECSA 19 Symposium. Estuaries and Coasts: Spatial and Temporal Intercomparisons, pp. 277-284. Olsen \& Olsen, Fredensborg, Denmark.

Poxton, M.G. (1987). Fishery studies in the estuary and Firth of Forth. Proceedings of the Royal Society of Edinburgh 93B, 495-508. https://doi.org/10.1017/S0269727000006904

Reynolds, J. (2004). Warning of 'dramatic decline' in Scottish sea trout. The Scotsman 23rd August.

Todd, C. (2014). Shrinking wild salmon starve at sea as North Atlantic warms. The Conversation, 21st January.

https://theconversation.com/shrinking-wild-salmonstarve-at-sea-as-north-atlantic-warms-22264 Accessed 10th November 2020.

Todd, C.D., Hughes, S.H., Marshall, C.T., MacLean, J.C., Lonergan, M. \& Biuw, E.M. (2008). Detrimental effects of recent ocean surface warming on growth condition of Atlantic salmon. Global Change Biology 14, 958-970. https://doi.org/10.1111/j.1365-2486.2007.01522.x

WFD CIS (2003a). Common Implementation Strategy for the Water Framework Directive (2000/60/EC). Guidance Document No. 5. Transitional and Coastal Waters - Typology, reference conditions and classification systems. Produced by Working Group 2.4 COAST. Directorate General Environment of the European Commission, Brussels, Belgium.

WFD CIS. (2003b). Common Implementation Strategy for the Water Framework Directive (2000/60/EC). Guidance Document No. 10. Rivers and Lakes Typology, reference conditions and classification systems. Produced by Working Group 2.3 REFCOND. Directorate General Environment of the European Commission, Brussels, Belgium.

WFD-UKTAG (2003). Guidance on Typology for Coastal and Transitional Waters of the UK and Republic of Ireland (Final). Water Framework Directive - United Kingdom Technical Advisory Group (WFD-UKTAG).

https://www.wfduk.org/sites/default/files/Media/Ch aracterisation $\% 20 \mathrm{of} \% 20$ the $\% 20$ water $\% 20$ environm ent/Marine\%20typology_Final_281003.pdf Accessed 6th June 2020.

WFD-UKTAG (2012). Practitioners Guide to the Transitional Fish Classification Index (TFCI) Water
Framework Directive: Transitional Waters. Version 07, 301112.

https://www.wfduk.org/sites/default/files/Media/En vironmental\%20standards/Annex\%2021\%20Transit ional\%20waters\%20Fish\%20TFCI.pdf Accessed 6th June 2020.

WFD-UKTAG (2014a). UKTAG Transitional Water Assessment Method - Fish fauna. Transitional Fish Classification Index. Water Framework Directive United Kingdom Technical Advisory Group (WFDUKTAG).

https://www.wfduk.org/sites/default/files/Media/Ch aracterisation $\% 20$ of $\% 20$ the $\% 20$ water $\% 20$ environm ent/Biological\%20Method\%20Statements/TW\%20 Fish\%20UKTAG\%20Method\%20Statement.pdf Accessed 6th June 2020.

WFD-UKTAG (2014b). Practitioners Guide to the Estuarine Multi-metric Fish Index (EMFI) Water Framework Directive: Transitional Waters. Version 01180814.

Whitfield, A.K. \& Elliott, M. (2002). Fishes as indicators of environmental and ecological changes within estuaries: A review of progress and some suggestions for the future. Journal of Fish Biology 61 A, 229-250.

https://doi.org/10.1111/j.1095-8649.2002.tb01773.x 